\title{
Global Value Chain Participation, Competition, and Markups: Evidence from Ethiopian Manufacturing Firms
}

\author{
Jieun Choi ${ }^{1}$, Emiko Fukase ${ }^{1+}$, and Albert G. Zeufack ${ }^{1}$ \\ ${ }^{1}$ World Bank, USA
}

\begin{abstract}
This study uses detailed manufacturing census panel data for 2000 to 2014 to explore the relationship between Ethiopian firms' global value chain (GVC) participation and markups. We find that GVC firms, defined as firms involved in both exporting and importing intermediate inputs, tend to have lower markups relative to non-trading firms and firms that are involved only in material imports. Moreover, the more intensely a firm is integrated into a GVC (measured by the share of export value added and imported inputs in total sales), the lower its markup is. Finally, we explore competition effects at the industry level and find that firms operating in industries with a relatively high GVC presence and suppliers selling inputs to such industries tend to have lower markups owing to horizontal competition and backward linkages, respectively. All of these findings suggest that GVC participation is associated with greater competition for Ethiopian firms.
\end{abstract}

Keywords: competition, Ethiopia, global value chain, markup

JEL Classifications: D22, F14, F61, L11, O14

Received 28 November 2020, Revised 18 June 2021, Accepted 23 July 2021

\section{Introduction}

Recent studies show that market power, as measured by markups (i.e., firms' abilities to charge prices above their marginal costs), tends to be rising globally.1) This change has been mainly driven by advanced economies, however, and the trend in developing countries is mixed (De Loecker \& Eeckhout, 2018; Diez et al., 2019). The emergence of global value chains (GVCs) is likely to have contributed to this phenomenon, as the fragmentation of production and changing trade patterns have influenced the competition that countries, industries, and firms face. The share of $\mathrm{GVC}^{2}$ ) trade (i.e., global exports that flow across at least two borders) in total world trade rose rapidly from about 40 percent in 1990 to 50 percent prior to the financial crisis

\footnotetext{
+Corresponding Author: Emiko Fukase

Consultant, World Bank, 1818 H Street, NW, Washington DC, 20433, USA. Tel: +1-917-873-4053.

Email: efukase@worldbank.org/emikof2@aol.com

Co-Author: Jieun Choi

Senior Economist, World Bank, 1818 H Street, NW, Washington DC, 20433, USA. Email: jieunchoi1121@gmail.com Co-Author: Albert G. Zeufack

Chief Economist, World Bank, 1818 H Street, NW, Washington DC, 20433, USA. Email: azeufack@worldbank.org
} 
in 2008, at which point it slowed somewhat (World Bank, 2019a).

The markups that firms derive from GVC participation may depend on the stages of the GVCs in which they participate. In turn, these stages are influenced by countries' economic development and comparative advantages. The consolidation and resilience of GVCs affect the levels of competition that economic agents face on boths the supply and demand sides of global production and distribution networks. Competition can change the distribution of the value added and markups across various producers by upgrading firms to higher value-added stages within GVCs (Gereffi, 2011; World Economic Forum, 2018). Within domestic value chains, markups may be influenced by the presence of GVC firms in an industry, which may affect both horizontal competition within industry and competition across industries (through backward and forward linkages).

In the United States and other advanced economies, the growth in markups may be driven by a relatively small number of superstar firms that are large, productive, highly profitable, and able to extract large markups (Autor et al., 2017; De Loecker \& Eeckhout, 2017; Diez et al., 2019). Global exports are also dominated by a small group of very large superstars (Freund \& Pierola, 2015). Fernandes et al. (2016) report that larger and richer countries have both more and larger exporters on average and a greater concentration of exports among the top five percent of exporting firms. GVC activities may have disproportionately benefited large firms in developed countries, as these firms can reduce their production costs by outsourcing labor-intensive components to low-wage countries and can benefit from the economies of scale created by exports (World Bank, 2019a).

In developing countries, the effects of GVC participation on local supplier markups and the prospects for upgrading depend on the type of GVC, GVC governance patterns, and countries' capabilities (Gereffi, 2011). On one hand, GVCs offer firms in developing countries opportunities to participate in global production networks in segments in which they have comparative advantages and to potentially upgrade to higher value activities. For instance, China has been strengthening its position in GVCs, improving its production mix, relying less on imported inputs, and increasing its competitiveness in domestic input sectors (Gereffi, 2011; Kee \& Tang, 2016). Fragmenting production across borders also allows for a finer division of labor across countries (World Bank, 2019a). Thus, GVCs may magnify the effects of trade on growth, employment, and functional specialization (Hummels et al., 2001; Linden et al., 2009; Timmer et al., 2019).

However, the benefits from GVCs may be unevenly distributed across and within countries;

1) Using financial statement data for more than 70,000 firms in 134 countries, De Loecker and Eeckhout (2018) estimate that the average global markup rose from nearly 1.1 in 1980 to around 1.6 in 2016 .

2) Different studies define GVCs differently, but most authors consider both imports and exports in defining a GVC; Taglioni and Winkler (2016) provide an overview. 
whereas large and productive buyers in developed countries tend to earn greater profits and markups owing to GVC participation, suppliers in developing countries may be squeezed (Lianos \& Lombardi, 2016; World Bank, 2019a; World Economic Forum, 2018).3) This outcome may be driven by fierce competition from other low-wage countries or the disproportionately high bargaining power of leading firms from advanced countries over their suppliers. However, little research has been conducted on the relationship between GVC participation and markups in low-income countries.

This study therefore investigates the relationship between GVC participation and markups in a low-income country, Ethiopia, using manufacturing census panel data from 2000 to 2014. We explore whether GVC firms, defined as firms that both import material inputs and export some of their products, have different markups relative to non-trading firms (referred to as "non-traders") and firms that participate in exports or raw material imports but not both (referred to as "one-way traders"). We estimate firm-level markups using De Loecker and Warzynski's method (2012).

Ethiopia provides an interesting setting for studying this topic. Since the turn of the millennium, Ethiopia's gross domestic product has grown quickly. Its per capita income has nearly tripled from $\$ 197$ in 2000 to $\$ 570$ in 20184) (World Bank, 2019b). With the government's efforts to industrialize and open the economy, the country's manufacturing GVC participation expanded substantially. Specifically, the number of GVC firms nearly tripled from 2000 and 2001 to 2013 and 2014.5) Although GVC firms account for only about four percent of Ethiopia's manufacturing firms, they tend to be large in terms of both sales and employment, as they accounted for 21 percent and 23 percent of total manufacturing sales and employment, respectively, in 2013 and 2014. Moreover, GVC firms are more productive, more capital intensive, and pay higher wages relative to non-traders and one-way traders when we control for year, regional, and sector fixed effects (see Figure 1 below).

Although numerous previous studies investigate the relationships of export status and access to imported inputs with firm productivity, fewer studies consider the relationship between firms' participation in trade and markups. Some models of international trade with heterogenous producers predict that exporters have a markup premium, as productive firms self-select into export markets and charge higher markups (Melitz \& Ottaviano, 2008). Several studies find empirical evidence supporting this prediction in advanced countries. For example, Bellone et al. (2016), Gullstrand

3) For example, in the textile and apparel GVCs, the World Bank (2019a) finds that markups and exports tend to be negatively related for supplying firms in selected developing countries, whereas buying firms in developed countries earn higher profits. Lianos and Lombardi (2016) report that powerful retail chains and large multinational food processing companies in agri-food value chains have been squeezing upstream suppliers with their superior bargaining power.

4) Dollar values are given at 2010 constant prices.

5) To mitigate the effects of yearly fluctuations, the earliest two years (2000 and 2001) and the latest two years (2013 and 2014) are averaged. 
et al. (2014), Kato (2014), and Békés et al. (2016) find markup premiums in France, Sweden, Japan, and four European Union countries, respectively.

For transition economies, however, the results appear to be mixed. De Loecker and Warzynski (2012) analyze data from Slovenia during its transition from a planned to a market economy following its independence from the former Yugoslavia. They find that markups were significantly higher for exporters than for non-exporters and increased when firms entered export markets. In contrast, considering firm-level data from Poland over the period from 2002 to 2016, Gradzewicz and Mućk find that markups in Poland, a supplier in European GVCs, have been falling over the past 15 years, particularly for exporters. Thus, the relationship between exports and markups remains an open question.

A reduction in the cost of imported inputs will reduce firms' marginal costs of production and increase their markups if they do not pass the entire cost savings through to the final price, as De Loecker et al. (2016) show for India and Brandt et al. (2017) report for China. Specifically, De Loecker et al. (2016) show that when input tariffs were reduced in India, firms that imported cheaper inputs did not reduce their sales prices to reflect the entire cost savings, and, thus, they increased their markups. Using data on Hungarian manufacturing firms, Hornok and Muraközy (2019) find that firms that import intermediate inputs charge higher markups because importing helps these firms produce higher quality outputs. However, importing more intermediate inputs is not always associated with lower costs. For example, in the context of Poland's participation in the European value chain, Gradzewicz and Mućk (2019) find that increasing reliance on imported inputs in production, along with rising competition among domestic firms for access to export markets, is a major factor in the observed reduction in markups.

Our study contributes to the literature on trade, GVCs, and development, particularly the literature on the relationship between GVC participation and competition. This study makes three important advancements. First, to the best of our knowledge, no previous study explores the relationship between GVC participation and markups in low-income countries. We aim to fill this gap by providing a case study of a low-income country, Ethiopia. Using the pooled ordinary least squares (OLS) method to conduct a cross-sectional analysis, we find that GVC firms tend to have lower markups relative to non-trading firms and firms that are involved only in importing raw materials. Investigating within-firm variation using a model with fixed effects, we observe that firms participating in GVCs tend to experience reductions in their markups relative to non-trading firms and firms involved only in imports. Our results are robust to including a variety of control variables, such as firm characteristics and sector, year, and regional fixed effects.

Second, this study investigates whether the depth of participation in a GVC (measured as the share of export value added and imported inputs in total sales) affects firms' markups by interacting firms' GVC participation with their trade intensity. We find that the degree of trade participation matters, that is, the more GVC firms are involved in exports and raw material 
imports, the lower their markups are.

Third, we investigate whether firms' markups are influenced by the presence of GVC firms at the industry level. GVC firms may introduce competitive pressure within their industries (horizontal competition) and may even extend this pressure to their suppliers and buyers through backward and forward linkages, respectively. We find that firms operating in industries with more GVC presence have lower markups through horizontal competition and that suppliers of inputs to industries with more GVC presence also have lower markups through backward linkages. All of these findings suggest that GVC participation is associated with greater competition in Ethiopia.

The remainder of this paper proceeds as follows. Section II describes our measures of GVC participation, the methods for obtaining markups, and trends in GVC participation and markups for Ethiopian manufacturing firms. Section III explains our estimation strategy and reports the regression results. Section IV presents our conclusions.

\section{Estimating GVC Participation and Markups}

\section{A. GVC participation - estimation and trends}

Many previous studies document the level of GVC participation at the country and industry level using global input-output tables, such as the World Input-Output Database (WIOD) (Timmer, 2012). This information reflects that for GVCs, unlike in the case of traditional trade, gross exports and imports are not accurate measures of the exported domestic value added and the foreign value added that is consumed, respectively. Studies using global input-output tables provide more accurate bilateral trade flows and bilateral value-added balances (Johnson \& Noguera, 2012; Koopman et al., 2014).

However, such global input-output tables as WIOD are unavailable for Ethiopia. Furthermore, despite their widespread use, these tables do not measure firms' participation in GVCs, as they rely on aggregated input-output data. Their sectoral disaggregations of GVC flows tend to be coarse, as they miss GVC activity within broadly defined sectors. Researchers are forced to impose strong assumptions in constructing the tables to estimate some bilateral intermediate input trade flows that cannot be readily determined from customs data or national input-output tables.

This study uses firm-level panel data on large and medium manufacturing industries (LMMI) (hereinafter, Ethiopian Manufacturing Census Data) collected annually by the Ethiopian Central Statistical Agency (CSA) from 2000 through 2014. The census covers all Ethiopian manufacturing establishments that have at least 10 employees and use electricity for production.6) The dataset

6) In 2011, the CSA changed its survey questionnaire and firm identification numbers. We merge the data for 2000 
provides detailed information on each firm's location, number of employees, capital, sales, production, exports and material imports, and wages and benefits. We classify manufacturing establishments according to the International Standard Industrial Classification (ISIC) at the four-digit level. We aggregate the data at the two-digit level to ensure that we have sufficient observations to run production functions for each industry.7)

We consider two firm-level measures of GVC participation:

- $G V C$ status $_{i t}=1$ if firm $i$ participates in both exporting and importing inputs at time $t$. - Trade Intensity It $=\frac{V A X_{i t}+\text { Int }_{i t}}{\text { Sales }_{i t}}$, where Trade Intensity It $_{i t}$ is the trade intensity of firm $i$ at time $t, V A X_{i t}$ is the value-added 8$)$ portion of export sales, Int $M_{i t}$ is the value of imported intermediate inputs, and Sales $_{i t}$ is the value of total sales.9)

Our first measure of GVC participation, GVC status, is a dummy variable equal to one for firms that both export and import intermediate inputs $(\mathrm{GVC}=1)$. We compare the performance of GVC firms with those of one-way traders and non-traders, that is, firms that export but do not import raw materials $($ OnlyX $=1)$, firms that do not export but import at least some of their materials $($ OnlyM $=1)$, and firms that neither export products nor import raw materials $(\mathrm{NoXM}=1)$. We group firms into these four categories because participating in imports or exports may require different and possibly higher capabilities than not participating in trade requires. Although these dummy variables are suitable for classifying firms into four mutually exclusive categories, however, they do not provide information about the extent of participation by firms in each category. Thus, in the empirical section (Section III.A), we consider a second measure of trade participation in which we interact trade status with trade intensity (regressions (5) and (6) in Table 4).

to 2011 with the data for 2011 to 2014 data using electricity identification numbers. These identification numbers are not available for some firms in the dataset, and this limitation of the merged panel data should be considered when interpreting the results. In the econometric analysis, we estimate a regression using only data for the years 2000 to 2010 and find similar results (see regression (2) in Table 5).

7) Specifically, we estimate production functions for 14 ISIC categories at the two-digit level. We include some ISIC industries with few observations under other ISIC codes. Tobacco products (ISIC 16) are included in food and beverages (ISIC 15), and coke and petroleum products (ISIC 23) are included in chemical products (ISIC 24). We also combine machinery and equipment (ISIC 29); office, accounting, and computing machinery (ISIC 30); electrical machinery (ISIC 31); radio, TV, and communication equipment (ISIC 32); medical, precision, and optical instruments (ISIC 33); and motor vehicles (ISIC 34) into one machinery category (ISIC 29-34).

8) Value-added is computed as follows: value-added = production - raw materials costs - other industrial costs other non-industrial expenses. Here, production $\approx$ sales + change in stock.

9) Adding (gross) export sales and imported material purchase values entails double counting because export sales include the cost of imported raw materials. To avoid this issue, we sum the value-added component of exports and imported materials and then divide this sum by total sales. We implicitly assume that the proportion of value-added in total sales is the same for the domestic and export markets. 
Our GVC measures are consistent with previous studies that define a GVC as a series of stages in the production of a product or service for sale to consumers such that each stage adds value and at least two stages are in different countries (World Bank, 2019a). Although the LMMI data do not provide direct information on firm-to-firm transactions across countries, our measures allow us to capture fine variation in GVC participation across firms within aggregated industries and do not require us to assume that bilateral intermediate input trade flows are the same within broadly defined sectors. Additionally, our measures allow us to compare levels of GVC participation across different firms. However, our GVC measures neither specify the form that the foreign value added in production takes, although it is often associated with trade in raw materials, intermediate inputs, and tasks, nor do they specify the shape of a GVC as either vertical or horizontal specializations crossing borders multiple times (Los et al., 2015; Wang et al., 2013).

Table 1. Number of Establishments, Sales and Employment of Ethiopian Manufacturing Firms 2000-2014, Total vs. GVC Firms

\begin{tabular}{|c|c|c|c|c|c|c|c|c|c|}
\hline & \multicolumn{3}{|c|}{ Number of Establishments } & \multicolumn{3}{|c|}{ Sales (million Birr) ${ }^{\mathrm{a}}$} & \multicolumn{3}{|c|}{ Employment } \\
\hline & $2000 / 2001$ & $2013 / 2014$ & $\begin{array}{c}\text { Annual } \\
\text { Growth (\%) }\end{array}$ & $2000 / 2001$ & $2013 / 2014$ & $\begin{array}{c}\text { Annual } \\
\text { Growth (\%) }\end{array}$ & $2000 / 2001$ & $2013 / 2014$ & $\begin{array}{c}\text { Annual } \\
\text { Growth (\%) }\end{array}$ \\
\hline Total & 708 & 2394 & 9.4 & 14476 & 73448 & 12.5 & 74987 & 199174 & 7.5 \\
\hline GVC firms & 32 & 88 & 7.7 & 3565 & 15646 & 11.4 & 14828 & 45032 & 8.6 \\
\hline GVC/Total (\%) & 4.5 & 3.7 & & 24.6 & 21.3 & & 19.8 & 22.6 & \\
\hline
\end{tabular}

Notes: Only establishments which employed ten or more employees are included.

${ }^{a}$ Sales deflated using manufacturing value added deflator available in FAOSTAT.

(Source) Ethiopian Manufacturing Census Data 2000-2014.

Table 1 shows trends in the number, sales, and employment of GVC firms relative to all manufacturing firms in the dataset. The first three columns in the table show that the number of Ethiopian establishments employing ten or more workers more than tripled from 708 to 2,394 establishments over the period from 2000 and 2001 to 2013 and 2014. During that same period, the number of GVC firms rose from 32 ( 4.5 percent of firms in the dataset) to 88 (3.7 percent of firms in the dataset).

The middle three columns show that the total (deflated) sales generated by the firms in our dataset rose from 14,476 million Ethiopian birr (ETB) in 2000 and 2001 to ETB 73,448 million in 2013 and 2014, and the last three columns show that number of workers that these firms employed increased from 74,987 to 199,174 . Annual output growth (12.5 percent) was faster than annual employment growth (7.5 percent) over this period, implying that sales per worker rose substantially. During the same period, sales generated by GVC firms rose from ETB 3,565 million in 2000 and 2001 to ETB 15,646 million in 2013 and 2014, implying an annual growth rate of 11.4 percent. By comparison, employment grew from 14,828 workers in 2000 and 2001 to 45,032 workers in 2013 and 2014, an average growth rate of 8.6 percent. These statistics 
imply that although Ethiopia has only a small number of GVC firms, they play an important role in the manufacturing sector, as they are responsible for substantial shares of sales (24.6 percent of total sales in 2000 and 2001 and 21.3 percent of total sales in 2013 and 2014) and employment (19.8 percent of total employment in 2000 and 2001 and 22.6 percent of total employment in 2013 and 2014).

Figure 1. Capital intensity, productivity and wage differences between trading firms and non-traders (\%)

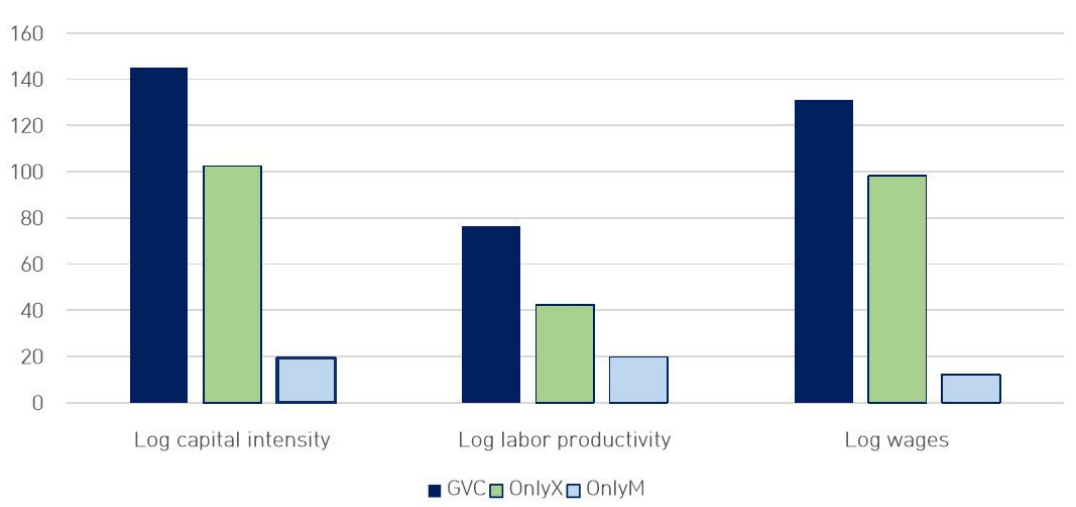

Notes: Figure 1 shows the percentage differences in $\log$ of capital intensity, $\log$ of labor productivity and $\log$ of wages between non-traders and trading firms. The results are obtained by regressing the log of capital intensity (capital per worker), log of labor productivity (sales per worker) and $\log$ of wages on dummy variables if the firm exports and imports inputs (GVC), exports only (OnlyX), and imports intermediate inputs only (OnlyM), controlling for sector, year, and regional fixed effects, as well as whether the firm is state-owned. Non-traders (NoXM) are omitted as the reference category. The labor productivity regression also controls for capital per worker. The percent differences reported in the figure are obtained as 100 multiplied by the exponential of the coefficient estimates minus 1 .

(Source) Ethiopian Manufacturing Census Data 2000-2014.

Figure 1 compares GVC firms with non-traders (NoXM) and one-way traders (OnlyX and OnlyM) in terms of capital intensity, labor productivity (i.e., sales per worker), and wage levels. The figure shows that GVC firms tend to be more capital-intensive and more productive (defined as labor productivity controlling for capital intensity) and pay higher wages relative to one-way traders or non-traders, controlling for regional, year, and industry fixed effects. The better performance of GVC firms is consistent with the large body of previous literature focusing on firm heterogeneity in international trade. Studies find that exporting firms, including those in sub-Saharan African countries (e.g., Bigsten et al., 2004; Fatou \& Choi, 2013; Mengistae \& Pattillo, 2004; Van Biesebroeck, 2005), tend to be larger and more productive and pay higher wages relative to non-exporting firms.

The observed better performance of GVC firms is also in line with previous work reporting the positive effects of access to imported inputs on productivity and product quality. For example, 
Abreha (2019) and Bigsten et al. (2016) find this result for Ethiopia. Amiti and Konings (2007), Halpern et al. (2015), and Topalova and Khandelwal (2011) consider Indonesia, Hungary, and India, respectively. Moreover, some studies, such as those of Castellani et al. (2010) in Italy, Smeets and Warzynski (2013) in Denmark, and Vogel and Wagner (2010) in Germany, find that two-way traders are more productive on average than firms that only import or export. This result is partly because the ability to export sometimes depends on the ability to import, as access to better intermediate inputs or new input goods and varieties facilitates product upgrades and creates new possibilities for exports. Studies by Bas and Strauss-Kahn (2015) in China and Goldberg et al. (2009) in India support this finding.

Table 2 reports the average proportions of GVC firms, one-way traders (OnlyX and OnlyM), and non-traders (NoXM) by industry over the period from 2000 to 2014. Column 1 shows that GVC firms are concentrated in a few sectors. For example, they make up 25.5 percent of leather and footwear (ISIC 19), 19.7 percent of textiles (ISIC 17), 10.7 percent of apparel (ISIC 18), and 3.7 percent of food and beverage (ISIC 15) firms.

Overall, Ethiopian manufacturing firms are characterized by low export participation; on average, just 4.7 percent of firms participated in exporting over the period from 2000 to 2014 (3.8 percent of all firms are GVC firms, and 0.9 percent are OnlyX firms). In contrast, trade participation on the import side (i.e., GVC and OnlyM firms) is high, with nearly two thirds (63.7 percent) of firms purchasing imported materials on average (3.8 percent of all firms are

Table 2. GVC and One-way Trade Participation by Industry (\%)

\begin{tabular}{|c|c|c|c|c|c|c|c|}
\hline \multirow{2}{*}{ ISIC } & \multirow{2}{*}{ Description } & \multicolumn{4}{|c|}{ Four Firm Categories } & \multirow{2}{*}{$\begin{array}{c}\text { GVC + } \\
\text { OnlyX }\end{array}$} & \multirow{2}{*}{$\begin{array}{l}\text { GVC+ } \\
\text { OnlyM }\end{array}$} \\
\hline & & GVC & OnlyX & OnlyM & NoXM & & \\
\hline 15 & Food and Beverages & 3.7 & 1.3 & 53.1 & 41.8 & 5.1 & 56.8 \\
\hline 17 & Textiles & 19.7 & 4.4 & 44.2 & 31.7 & 24.0 & 63.9 \\
\hline 18 & Apparel & 10.7 & 5.0 & 54.2 & 30.1 & 15.7 & 64.9 \\
\hline 19 & Leather \& Footwear & 25.5 & 3.2 & 50.8 & 20.6 & 28.6 & 76.3 \\
\hline 20 & Wood products & 0.1 & 0.2 & 44.2 & 55.5 & 0.3 & 44.3 \\
\hline 21 & Paper \& Paper products & 1.1 & 0.0 & 90.7 & 8.2 & 1.1 & 91.8 \\
\hline 22 & Publishing \& Printing & 0.2 & 0.1 & 81.9 & 17.7 & 0.4 & 82.1 \\
\hline 24 & Chemicals & 2.6 & 0.4 & 86.1 & 10.9 & 3.0 & 88.7 \\
\hline 25 & Rubber \& Plastics & 0.8 & 0.1 & 90.8 & 8.2 & 1.0 & 91.6 \\
\hline 26 & Non-metallic mineral products & 0.7 & 0.5 & 26.1 & 72.8 & 1.1 & 26.7 \\
\hline 27 & Basic metals & 0.6 & 0.5 & 94.3 & 4.5 & 1.2 & 95.0 \\
\hline 28 & Fabricated Metal products & 1.0 & 0.2 & 78.6 & 20.2 & 1.2 & 79.6 \\
\hline $29-34$ & Machinery 29,30,31,32,33,34 & 1.0 & 0.4 & 81.2 & 17.4 & 1.4 & 82.2 \\
\hline \multirow[t]{2}{*}{36} & Furniture & 0.3 & 0.2 & 78.2 & 21.3 & 0.5 & 78.6 \\
\hline & Total & 3.8 & 0.9 & 59.9 & 35.3 & 4.7 & 63.7 \\
\hline
\end{tabular}

(Source) Ethiopian Manufacturing Census Data 2000-2014. 
GVC firms, and 59.9 percent are OnlyM firms). From 2000 to 2014, 35.3 percent of establishments participated in neither exports nor material imports.

\section{B. Estimating markups}

Following De Loecker and Warzynski (2012), we use the firm-level markup, that is, the percentage difference between a firm's marginal cost and its selling price, as a measure of competition. We assume that firms are cost-minimizing and that technology can be described by a Cobb-Douglas production function. We estimate separate production functions for each two-digit ISIC sector using Ackerberg et al.'s (2006) method.

A cost-minimizing firm $i$ produces output at time $t$ using the following production technology:

$$
Q_{i t}=Q_{i t}\left(L_{i t}, M_{i t}, K_{i t}, \omega_{i t}\right)
$$

where $L_{i t}, M_{i t}$, and $K_{i t}$ denote labor, intermediate inputs, and capital assets, respectively, and $\omega_{i t}$ is the firm-specific productivity. $Q_{i t}$ ( ) is continuous and is twice differentiable with respect to its arguments. The associated Lagrangian function is:

$$
\mathscr{L}\left(L_{i t}, M_{i t}, K_{i t}, \lambda_{i t}\right)=w_{i t} L_{i t}+p_{i t}^{M} M_{i t}+r_{i t} K_{i t}+\lambda_{i t}\left(Q_{i t}-Q_{i t}(\cdot)\right),
$$

where $w_{i t}, p_{i t}^{M}$, and $r_{i t}$ denote the labor, materials, and capital prices, respectively, for a firm.

The first-order condition for material inputs is

- $\frac{\partial \mathscr{L}_{i t}}{\partial M_{i t}}=p_{i t}^{M}-\lambda_{i t} \frac{\partial Q_{i t}(\cdot)}{\partial M_{i t}}=0$, where the marginal cost of production at a given level of output is $\lambda_{i t}$, as $\frac{\partial \mathscr{L}_{i t}}{\partial Q_{i t}}=\lambda_{i t}$. Rearranging the terms and multiplying both sides by $\frac{M_{i t}}{Q_{i t}}$, we obtain $\frac{\partial Q_{i t}(\cdot)}{\partial M_{i t}} \frac{M_{i t}}{Q_{i t}}=\frac{1}{\lambda_{i t}} \frac{p_{i t}^{M} M_{i t}}{Q_{i t}}$.

The variable on the left-hand side is the output elasticity of the material input denoted as $\Theta_{i t}^{M}$. Thus, the equation implies that a cost-minimizing firm sets its optimal material input such that the output elasticity of the material input equals the product of the material price and the share of the material input in production divided by marginal cost of production at a given level of output. Here, we use material inputs to estimate markups. However, this marginal 
cost of production can be derived from the first-order condition for any non-dynamic input variable (e.g., labor input).

We deflate sales and input costs as proxies for quantity terms. ${ }^{10)}$ Thus, our estimated markups may include information besides the level of competition, such as the perceived quality of products and a firm's ability to produce differentiated goods. However, De Loecker and Warzynski (2012) show that although deflated sales may alter the levels of markups, they do not affect the correlation between markups and firm-level characteristics or changes in markups over time.

Defining the markup $\mu_{i t}$ as the ratio of the price to the marginal cost, $\mu_{i t} \equiv \frac{P_{i t}}{\lambda_{i t}}$, we can estimate the markup using the material coefficient $\Theta_{i t}^{M}$.

$$
\Theta_{i t}^{M}=\mu_{i t} \frac{p_{i t}^{M} M_{i t}}{P_{i t} Q_{i t}} \text { and } \mu_{i t}=\Theta_{i t}^{M}\left(\frac{p_{i t}^{M} M_{i t}}{P_{i t} Q_{i t}}\right)^{-1}
$$

Because the sales term $\left(P_{i t} Q_{i t}\right)$ includes $\varepsilon_{i t}$, an unobservable and unanticipated shock to production (e.g., exogenous circumstances and unanticipated delays), and independent and identically distributed shocks, including measurement error, we remove $\varepsilon_{i t}$ by estimating sales as $P_{i t} Q_{i t} / \widehat{\varepsilon_{i t}}$. Thus, the markup is estimated as

$$
\mu_{i t}=\Theta_{i t}^{M}\left(\frac{p_{i t}^{M} M_{i t}}{P_{i t} Q_{i t}}\right)^{-1} \exp \left(\widehat{\varepsilon_{i t}}\right) .
$$

Table 3 shows the median markup by industry on average over the period from 2001 to 2014. The first column shows that the median markup in Ethiopian manufacturing firms is 1.55 . The markups vary across industries. Non-metallic mineral products (ISIC 26) has a relatively high estimated markup of 2.24, whereas those of chemicals (ISIC 24), basic metals (ISIC 27), food and beverages (ISIC 15), and leather and footwear (ISIC 19) are relatively low at 1.19, $1.22,1.29$, and 1.30 , respectively. Columns $2-3$ of Table 3 show that the median markup declined from 1.62 in 2001 and 2002 to 1.52 in 2013 and 2014.

10) We define capital as the value of fixed assets at the beginning of the year deflated by the gross fixed capital formation deflator provided by the Food and Agriculture Organization Statistical Database (FAOSTAT). The values of sales and material inputs are deflated by the manufacturing value-added deflator obtained from FAOSTAT. 
Table 3. Median Markups by Industry

\begin{tabular}{clccc}
\hline ISIC & \multicolumn{1}{c}{ Description } & $2001-2014$ & $2001 / 2002$ & $2013 / 2014$ \\
\hline 15 & Food and Beverages & 1.29 & 1.31 & 1.19 \\
17 & Textiles & 1.40 & 1.61 & 1.33 \\
18 & Apparel & 1.58 & 1.55 & 1.79 \\
19 & Leather \& Footwear & 1.30 & 1.21 & 1.36 \\
20 & Wood products & 1.85 & 2.69 & 1.61 \\
21 & Paper \& Paper products & 1.83 & 1.59 & 1.70 \\
22 & Publishing \& Printing & 1.72 & 1.83 & 1.25 \\
24 & Chemicals & 1.19 & 1.18 & 1.40 \\
25 & Rubber \& Plastics & 1.54 & 1.71 & 2.40 \\
26 & Non-metallic mineral products & 2.24 & 2.25 & 1.20 \\
27 & Basic metals & 1.22 & 1.11 & 1.61 \\
28 & Fabricated Metal products & 1.52 & 1.80 & 1.33 \\
$29-34$ & Machinery 29,30,31,32,33,34 & 1.74 & 2.03 & 1.76 \\
36 & Furniture & 1.84 & 2.10 & 1.52 \\
\hline
\end{tabular}

(Source) Ethiopian Manufacturing Census Data 2000-2014.

Figure 2. Evolution of median markup 2001-2014.

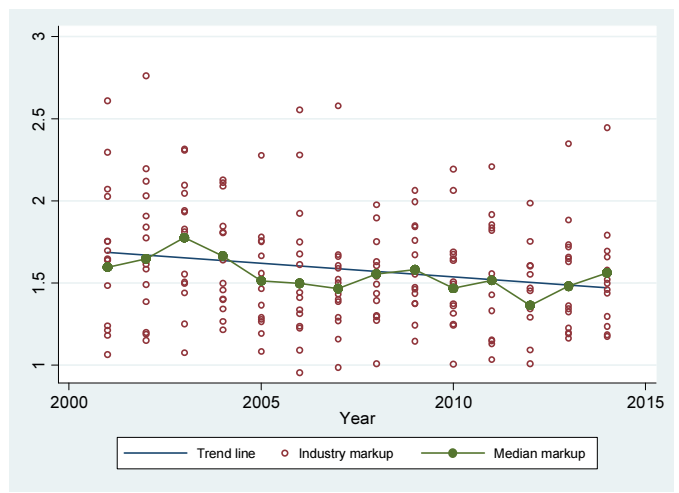

(Source) Ethiopian Manufacturing Census Data 2000-2014. (Source) Ethiopian Manufacturing Census Data 2000-2014.
Figure 3. Distribution of $\log$ of markups by trade participation status.

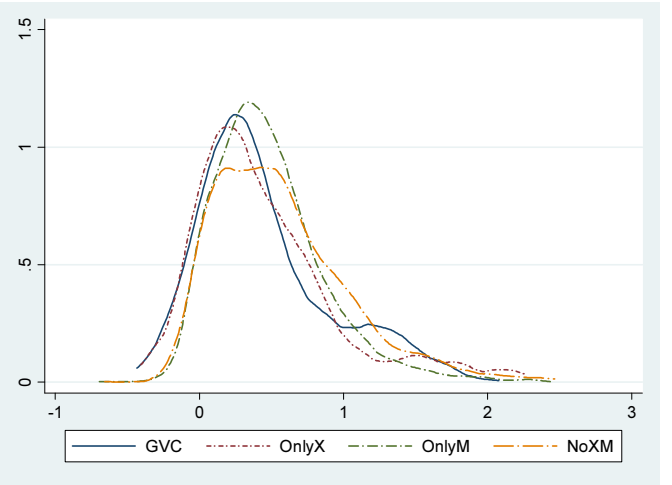

Figure 2 shows the historic trends in estimated markups over the period from 2001 to 2014. We show the median markups for the manufacturing industry as a whole and the median markups for each industry. The estimated markups fluctuate from year to year, but the figure shows that markups have slightly decreased over the estimation period.

Figure 3 shows the distribution of markups across the four trade participation categories. The markup distributions for OnlyM and NoXM firms lie to the right of the markup distributions for GVC and OnlyX firms, suggesting that GVC firms and firms that participate only in exports may have lower markups relative to non-trading firms and firms that participate only in material imports. 


\section{Estimation Strategy and Regression Results}

\section{A. GVC participation and markups}

Our regression model is

$$
\ln \mu_{i t}=\alpha G V C_{i t}+\beta X_{i t}+\gamma Y_{j}+\rho_{t}+\tau_{l}+v_{i t}
$$

where $\ln \mu_{i t}$ is the logarithm of the markup for firm $i$ in year $t$, defined as in equation (1) (De Loecker \& Warzynski, 2012). $G V C_{i t}$ is the set of GVC participation measures defined in Section II.A, namely, GVC status $s_{i t}$ and Trade Intensity ${ }_{i t}$, and $X_{i t}$ is a set of firm characteristics, including the logarithm of labor as a proxy for firm size and the logarithm of capital to capture capital intensity.

State ownership may affect the level of market competition through various channels, such as stricter regulations, barriers to entry for new and foreign firms, and government supports and incentives that disproportionally benefit state-owned firms (Dewenter \& Malatesta, 2001; Gupta, 2005; Megginson \& Netter, 2001). Consistent with the government's privatization programs (Oqubay, 2015), the share of state-owned firms in total firms in the Ethiopian Manufacturing Census declined from 17.4 percent in 2000 to 3.7 percent in 2014. To control for the effect of state ownership, we include a dummy variable indicating whether a firm is state-owned ${ }^{11)}$ in our regressions (this variable equals one for state-owned firms and zero for private firms). $Y_{j}$ is a set of industry-specific variables, such as the upstream index (Antràs et al., 2012) and industry dummies (i.e., 19 ISIC dummies), $\rho_{\mathrm{t}}$ is a set of year dummies (for 14 years), $\tau_{1}$ is a set of location dummies (for 12 regions), and $v_{i t}$ is the error term. Appendix Table 1 reports summary statistics for the variables included in the regressions.

Table 4 shows the results of estimating a series of pooled OLS regressions relating markups with measures of trade participation. Controlling for firm characteristics (regression (1)), the coefficients of the trade participation status dummies are significantly negative, suggesting that firms' trade participation is negatively associated with their markups. In particular, the coefficient of GVC firms (GVC) is the largest in magnitude, followed by the coefficients of export only (OnlyX) and import only firms (OnlyM). Adding regional and year dummies does not greatly alter the results (regression (2)). Introducing ISIC dummies, as in regression (3), considerably reduces the explanatory power of the GVC and one-way trade participation dummies, as the coefficients of OnlyX and OnlyM lose statistical significance, and the coefficient of GVC firms is significant only at the ten percent level. This result may arise because controlling for industry dummies may

11) The census asks if a firm is private, public, or public and private. The firms that responded "public" are defined as state-owned. The census provides no information on whether a firm is foreign. 
purge industry-level characteristics that are correlated with trade participation status.

Regression (4) includes the upstreamness index ${ }^{12}$ ), which measures the relative position of an industry in the production chain (Antràs et al., 2012), in place of ISIC dummies. The upstreamness index is always greater than or equal to one $(\geq 1)$. Larger values are associated with relatively higher levels of upstreamness of an industry's output. The coefficient of the upstreamness index is significantly positive, suggesting that firms operating in more upstream industries tend to have higher markups. Notably, some of the industries in which Ethiopia's GVC firms are concentrated, namely, apparel and leather and footwear, appear to be downstream industries, with upstreamness indexes of 1.01 and 1.04, respectively. The lack of competition in upstream sectors, that is, industries that tend to supply raw materials or intermediate inputs, may partly explain why so many Ethiopian firms rely on imported intermediary inputs for production rather than using domestic inputs produced by firms with high markups. The coefficients of the GVC and one-way trade participation dummies remain essentially unchanged when we adjust for the upstreamness of industries.

In all of the specifications, the coefficients of the dummies for GVC participation are significantly negative, suggesting that GVC firms charge lower markups than non-trading firms (NoXM) do. To test whether GVC firms charge different markups than one-way traders do, we conduct an $F$-test for the statistical difference between the coefficient of GVC status and coefficients of firms involved in only exports (OnlyX $=\mathrm{GVC}$ ) and only importing materials (OnlyM $=\mathrm{GVC}$ ). Table 4 reports the results. In two of the four specifications, OnlyM $=\mathrm{GVC}$ can be rejected, implying that GVC-participating firms have lower markups than firms participating only in material imports do. OnlyX $=\mathrm{GVC}$ cannot be rejected in any of the specifications, and, thus, we find no evidence that GVC-participating firms and firms involved in exports but not material imports charge different markups.

The negative coefficient of the OnlyM dummy variable may seem counterintuitive and inconsistent with previous studies finding that a decrease in the cost of imported inputs positively affects markups (e.g., De Loecker et al., 2016) and previous studies suggesting that importing intermediate inputs is associated with a markup premium because these imports lead to higherquality outputs (e.g., Hornok \& Muraközy, 2019). A potential explanation is that importing materials may be costlier than sourcing domestic inputs, as is the case in Poland (Gradzewicz \& Mućk, 2019), if, for instance, imported goods are more expensive owing to their higher quality13) or require higher transportation or transaction costs. With incomplete passthrough of costs to consumers, importing firms may need to lower their markups. Another potential explanation is that the coefficient

12) The upstreamness index is an industry measure of relative production line positions that is computed as the average distance from final use in the production chain (Antràs et al., 2012). This index is calculated using the input-output table for Ethiopia from the Global Trade Analysis Project (GTAP) database for 2011 (https://www.gtap.agecon.purd ue.edu/). We map ISIC codes at the four-digit level for each firm to GTAP categories using the concordance developed by Francois et al. (2014).

13) Abreha (2019) reports that most of Ethiopia's manufacturing imports come from developed countries. 
estimate for OnlyM is biased owing to the omission of variables that represent a competitive business environment (relative to the environment faced by non-traders) and that are correlated with both import participation and markups. Many variables, such as better infrastructure;14) a supportive business and investment climate; and favorable geographical conditions, such as access to seaports, may positively affect firms' import participation and negatively affect their markups. Not controlling for these variables may have caused us to overestimate the coefficient of the import participation dummy. We address this potential problem by controlling for all (time-invariant) firm- and location-specific characteristics using a fixed effects model, and we find that the coefficient of OnlyM is insignificant (see regressions (1)-(3) in Table 5).

Finally, regression (5) estimates the relation between the depth of trade and markups by interacting the trade participation variables with trade intensity. The negative slopes of the interaction terms imply that for a given trade participation status, firms with higher trade intensities tend to have lower markups. Based on the estimated coefficients for regression (5), Figure 4 shows differences in the predicted means of markups depending on trade intensity.

Table 4. Pooled OLS Regression Results Relating Trade Participation and Markups

\begin{tabular}{|c|c|c|c|c|c|c|c|}
\hline & (1) & (2) & (3) & (4) & (5) & (6) & (7) \\
\hline \multicolumn{8}{|l|}{ Participation dummies ${ }^{\mathrm{a}}$ : } \\
\hline OnlyX & $\begin{array}{c}-0.109 * * \\
(0.048)\end{array}$ & $\begin{array}{c}-0.103^{* *} \\
(0.047)\end{array}$ & $\begin{array}{c}0.015 \\
(0.043)\end{array}$ & $\begin{array}{c}-0.094 * * \\
(0.047)\end{array}$ & $\begin{array}{l}-0.068 \\
(0.070)\end{array}$ & $\begin{array}{c}0.019 \\
(0.056)\end{array}$ & \\
\hline OnlyM & $\begin{array}{c}-0.084 * * * \\
(0.010)\end{array}$ & $\begin{array}{c}-0.095 * * * \\
(0.010)\end{array}$ & $\begin{array}{l}-0.007 \\
(0.009)\end{array}$ & $\begin{array}{c}-0.126^{* * *} \\
(0.010)\end{array}$ & $\begin{array}{c}0.072 * * * \\
(0.012)\end{array}$ & $\begin{array}{c}0.106 * * * \\
(0.010)\end{array}$ & \\
\hline GVC & $\begin{array}{c}-0.163^{* * * *} \\
(0.023)\end{array}$ & $\begin{array}{c}-0.177 * * * \\
(0.023)\end{array}$ & $\begin{array}{l}-0.039^{*} \\
(0.022)\end{array}$ & $\begin{array}{c}-0.160 * * * \\
(0.023)\end{array}$ & $\begin{array}{l}-0.004 \\
(0.037)\end{array}$ & $\begin{array}{l}0.064^{*} \\
(0.036)\end{array}$ & \\
\hline \multicolumn{8}{|c|}{ Participation dummies*Trade intensity: } \\
\hline OnlyX*Trade intensity & & & & & $\begin{array}{l}-0.112 \\
(0.106)\end{array}$ & $\begin{array}{l}-0.057 \\
(0.090)\end{array}$ & \\
\hline OnlyM*Trade intensity & & & & & $\begin{array}{c}-0.520 * * * \\
(0.017)\end{array}$ & $\begin{array}{c}-0.503^{* * *} \\
(0.019)\end{array}$ & \\
\hline GVC*Trade intensity & & & & & $\begin{array}{c}-0.460 * * * \\
(0.100)\end{array}$ & $\begin{array}{c}-0.514 * * * \\
(0.100)\end{array}$ & \\
\hline Trade Intensity & & & & & & & $\begin{array}{c}-0.379 * * * \\
(0.016)\end{array}$ \\
\hline $\begin{array}{l}\text { State ownership } \\
(=1 \text { state },=0 \text { private })\end{array}$ & $\begin{array}{c}0.152 * * * \\
(0.018)\end{array}$ & $\begin{array}{c}0.130 * * * \\
(0.018)\end{array}$ & $\begin{array}{c}0.092 * * * \\
(0.015)\end{array}$ & $\begin{array}{c}0.118 * * * \\
(0.018)\end{array}$ & & $\begin{array}{c}0.059 * * * \\
(0.015)\end{array}$ & $\begin{array}{c}0.060 * * * \\
(0.015)\end{array}$ \\
\hline Firm size (log of labor) & $\begin{array}{c}0.036^{* * *} \\
(0.005)\end{array}$ & $\begin{array}{c}0.044^{* * *} \\
(0.005)\end{array}$ & $\begin{array}{c}0.058^{* * *} \\
(0.005)\end{array}$ & $\begin{array}{c}0.044 * * * \\
(0.005)\end{array}$ & & $\begin{array}{c}0.056^{* * *} \\
(0.005)\end{array}$ & $\begin{array}{c}0.060^{* * *} \\
(0.005)\end{array}$ \\
\hline
\end{tabular}

14) For instance, Jones et al. (2018) report that firms that operate in markets with high transport costs appear to be shielded from competition to some extent. Because high transport costs may be negatively correlated with import participation and positively associated with markups, not controlling for transport costs may bias downwards the coefficient of the dummy variable for firms that only import materials. 
Table 4. Continued

\begin{tabular}{|c|c|c|c|c|c|c|c|}
\hline & (1) & (2) & (3) & (4) & (5) & (6) & (7) \\
\hline Log of capital & $\begin{array}{c}-0.022 * * * \\
(0.002)\end{array}$ & $\begin{array}{c}-0.021 * * * \\
(0.002)\end{array}$ & $\begin{array}{l}-0.001 \\
(0.002)\end{array}$ & $\begin{array}{c}-0.019 * * * \\
(0.002)\end{array}$ & & $\begin{array}{c}0.003 \\
(0.002)\end{array}$ & $\begin{array}{c}0.002 \\
(0.002)\end{array}$ \\
\hline Upstream index & & & & $\begin{array}{c}0.122 * * * \\
(0.007)\end{array}$ & & & \\
\hline Constant & $\begin{array}{c}0.727 * * * \\
(0.024)\end{array}$ & $\begin{array}{c}0.740 * * * \\
(0.110)\end{array}$ & $\begin{array}{c}-0.192 * * \\
(0.090)\end{array}$ & $\begin{array}{c}0.470 * * * \\
(0.090)\end{array}$ & $\begin{array}{c}0.564 * * * \\
(0.008)\end{array}$ & $\begin{array}{c}0.462 * * * \\
(0.031)\end{array}$ & $\begin{array}{c}0.224 * * \\
(0.096)\end{array}$ \\
\hline Year dummies & & $\mathrm{X}$ & $X$ & $X$ & & $\mathrm{X}$ & $X$ \\
\hline Regional dummies & & $\mathrm{X}$ & $\mathrm{X}$ & $\mathrm{X}$ & & $\mathrm{X}$ & $\mathrm{X}$ \\
\hline ISIC dummies & & & $X$ & & & $\mathrm{X}$ & $\mathrm{X}$ \\
\hline Number of observations & 10324 & 10324 & 10324 & 10323 & 10227 & 10227 & 10227 \\
\hline $\mathrm{R}^{2}$ & 0.036 & 0.062 & 0.297 & 0.082 & 0.071 & 0.339 & 0.329 \\
\hline$F$-stat $($ OnlyX $=\mathrm{GVC})$ & 1.12 & 2.18 & 1.40 & 1.74 & & & \\
\hline Prob $F>0$ & 0.290 & 0.140 & 0.238 & 0.186 & & & \\
\hline$F$-start $($ OnlyM $=\mathrm{GVC})$ & 13.91 & 15.21 & 2.38 & 2.50 & & & \\
\hline Prob $F>0$ & 0.000 & 0.000 & 0.123 & 0.114 & & & \\
\hline \multicolumn{5}{|c|}{$F$-stat $($ OnlyX $=$ OnlyX $*$ Trade intensity $=0)$} & 3.530 & 0.01 & \\
\hline \multicolumn{5}{|l|}{ Prob $F>0$} & 0.029 & 0.812 & \\
\hline \multicolumn{5}{|c|}{$F$-stat $($ OnlyM $=$ OnlyM $*$ Trade intensity $=0)$} & 602.71 & 367.27 & \\
\hline \multicolumn{5}{|l|}{ Prob $F>0$} & 0.000 & 0.000 & \\
\hline \multicolumn{5}{|c|}{$F$-stat $\left(\mathrm{GVC}=\mathrm{GVC}^{*}\right.$ Trade intensity $\left.=0\right)$} & 33.79 & 19.65 & \\
\hline \multicolumn{5}{|l|}{ Prob $F>0$} & 0.000 & 0.000 & \\
\hline
\end{tabular}

Notes: The dependent variable is the log of markup, estimated using the ACF method.

${ }^{a}$ Firms that have no trade (NoXM) are omitted as a reference category.

Standard errors are in parentheses. *, **, and *** indicate that the coefficients are significant at the 10,5 , and 1 percent level, respectively.

Figure 4. Trade intensity and predicted means of markups.

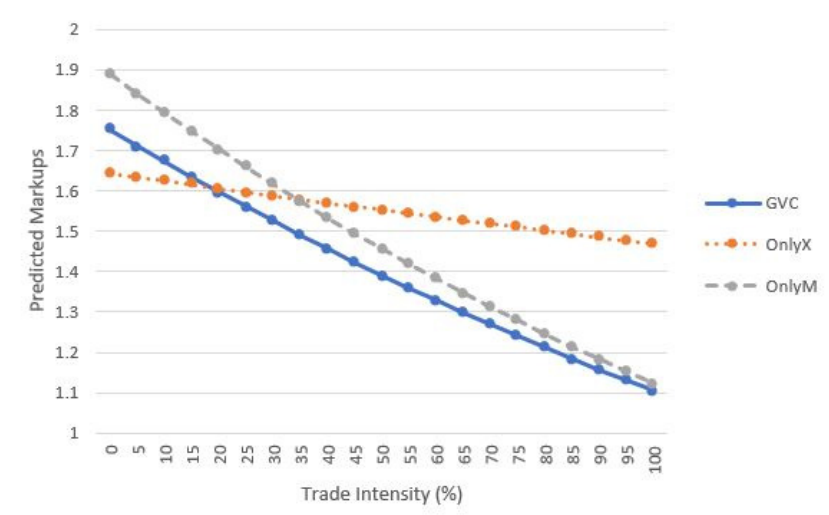

Notes: The predicted means of markups are calculated based on the coefficient estimates reported in regression (5) in Table 4. To obtain predicted markup levels, predicted $\log$ of markups are exponentiated.

(Source) Ethiopian Manufacturing Census Data 2000-2014. 
As trade intensity increases, the markups of GVC firms and firms that only import materials (OnlyM) decrease and approach one, whereas the slope for firms involved only in exports (OnlyX) is less steep.

The joint significance tests reported in the last six rows of Table 4 reveal that the coefficients of trade participation status and the interaction term are jointly significant for GVC and OnlyM firms at the one percent level and for OnlyX firms at the five percent level. When we introduce firm characteristics and region, year, and ISIC dummies as control variables in regression (6), the coefficients of the interaction terms remain negative. However, the results of the joint significance tests show that the two variables are no longer jointly significant for OnlyX firms, whereas they remain jointly significant for GVC and OnlyM firms at the one percent level. The somewhat imprecise results for OnlyX firms may partly reflect the small number of OnlyX firms, which comprise about one percent of all firms. Evaluated at the sample means of trade intensity, the implied combined impacts of trade participation and intensity for GVC and OnlyM firms relative to non-trading firms (NoXM) are -0.056 and -0.040 , respectively, in logarithm terms. ${ }^{15)}$ Regression (7) is an alternative specification that includes the trade intensity variable for each firm but excludes the trade participation dummy variables. The coefficient of the trade intensity variable is significantly negative at the one percent level, confirming that deeper trade participation is associated with lower markups. In all of the regressions, the coefficient of state ownership is significantly positive at the one percent level, suggesting that state-owned firms charge higher markups than private firms do.

Table 5 reports the results of regressions using the fixed effects model, which utilizes the variation within firms. Regression (1) includes controls for firm characteristics and year dummies. Because a firm's location and ISIC industry do not typically change over time, we do not include regional and ISIC dummies in this model. Although the magnitudes of the coefficients are smaller relative to the estimates obtained by pooled OLS, the coefficients of the GVC and OnlyX dummies remain significantly negative, suggesting that firms tend to lower their markups when they participate in either exports or both exports and material imports. Because the fixed effects model controls for any time-invariant unobservable firm- and location-specific effects, the coefficients of the OnlyM dummy are not significant, implying that non-trading firms do not alter their markups when they begin to import material inputs. The $F$-test results show that the hypothesis OnlyM = GVC can be rejected, confirming that participating in GVCs and only importing material inputs have different impacts on firms. One caveat for our merged panel dataset is that the firm identification numbers changed around 2011, and merging the data before and after 2011 led to some firms being excluded. As a robustness check, we run a regression using only the data from 2001 to 2010 and find similar results to those for the full sample (regression (2)).

15) The effect of GVC participation in logarithm terms is calculated at the mean of trade intensity $(0.235):-0.056 \approx$ $0.064-0.514 * 0.235$. 
Table 5. Fixed Effects Regression Results Relating Trade Participation and Markups

\begin{tabular}{|c|c|c|c|c|}
\hline & (1) & (2) & (3) & (4) \\
\hline \multicolumn{5}{|l|}{ Participation dummies ${ }^{\mathrm{a}}$ : } \\
\hline \multirow[t]{2}{*}{ OnlyX } & $-0.085^{* *}$ & $-0.089 *$ & -0.033 & \\
\hline & $(0.039)$ & $(0.046)$ & $(0.040)$ & \\
\hline \multirow[t]{2}{*}{ OnlyM } & -0.011 & -0.000 & $0.077 * * *$ & \\
\hline & $(0.010)$ & $(0.013)$ & $(0.012)$ & \\
\hline \multirow[t]{2}{*}{ GVC } & $-0.083 * *$ & $-0.095 * *$ & -0.039 & \\
\hline & $(0.034)$ & $(0.038)$ & $(0.045)$ & \\
\hline \multicolumn{5}{|c|}{ Participation dummies*Trade intensity } \\
\hline \multirow[t]{2}{*}{ OnlyX*Trade intensity } & & & -0.119 & \\
\hline & & & $(0.119)$ & \\
\hline \multirow[t]{2}{*}{ OnlyM*Trade intensity } & & & $-0.423 * * *$ & \\
\hline & & & $(0.030)$ & \\
\hline \multirow[t]{2}{*}{ GVC*Trade intensity } & & & -0.183 & \\
\hline & & & $(0.152)$ & \\
\hline \multirow[t]{2}{*}{ Trade intensity } & & & & $-0.323 * * *$ \\
\hline & & & & $(0.026)$ \\
\hline \multirow{2}{*}{$\begin{array}{l}\text { State ownership } \\
(=1 \text { state },=0 \text { private })\end{array}$} & -0.025 & -0.018 & -0.027 & -0.027 \\
\hline & $(0.029)$ & $(0.031)$ & $(0.029)$ & $(0.029)$ \\
\hline \multirow[t]{2}{*}{ Firm size (log of labor) } & $0.090 * * *$ & $0.066 * * *$ & $0.095 * * *$ & $0.098 * * *$ \\
\hline & $(0.010)$ & $(0.012)$ & $(0.010)$ & $(0.010)$ \\
\hline \multirow[t]{2}{*}{ Log of capital } & $0.008^{*}$ & $0.013 * *$ & $0.008 *$ & $0.008^{*}$ \\
\hline & $(0.004)$ & $(0.005)$ & $(0.004)$ & $(0.004)$ \\
\hline \multirow[t]{2}{*}{ Constant } & 0.100 & 0.101 & $0.120^{*}$ & 0.205 \\
\hline & $(0.069)$ & $(0.080)$ & $(0.067)$ & $(0.145)$ \\
\hline Year dummies & $\mathrm{X}$ & & $\mathrm{X}$ & $\mathrm{X}$ \\
\hline Number of observations & 10324 & 6910 & 10227 & 10227 \\
\hline $\mathrm{R}^{2}$ & 0.065 & 0.023 & 0.119 & 0.117 \\
\hline$F$-stat $($ OnlyX $=$ GVC $)$ & 0.00 & 0.01 & & \\
\hline Prob $F>0$ & 0.955 & 0.907 & & \\
\hline$F$-start $($ OnlyM $=$ GVC $)$ & 4.75 & 6.70 & & \\
\hline Prob $F>0$ & 0.029 & 0.009 & & \\
\hline \multicolumn{2}{|c|}{$F$-stat $\left(\right.$ OnlyX $=$ OnlyX ${ }^{*}$ Trade intensity $\left.=0\right)$} & & 1.76 & \\
\hline \multicolumn{2}{|l|}{ Prob $F>0$} & & 0.172 & \\
\hline \multicolumn{2}{|c|}{$F$-stat $($ OnlyM $=$ OnlyM $*$ Trade intensity $=0)$} & & 96.95 & \\
\hline \multicolumn{2}{|l|}{ Prob $F>0$} & & 0.000 & \\
\hline \multicolumn{2}{|c|}{$F$-stat $\left(\mathrm{GVC}=\mathrm{GVC}^{*}\right.$ Trade intensity $\left.=0\right)$} & & 2.98 & \\
\hline \multicolumn{2}{|l|}{ Prob $F>0$} & & 0.051 & \\
\hline
\end{tabular}

Notes: The dependent variable is the log of markup, estimated by the ACF method.

${ }^{a}$ Firms that have no trade (NoXM) are omitted as a reference category.

Standard errors are in parentheses. ${ }^{*}, * *$, and $* * *$ indicate that the coefficients are significant at the 10,5 , and 1 percent level, respectively. 
Regression (3) includes the interactions between the trade participation dummies and trade intensity, controlling for firm characteristics and year dummies. We find that the coefficients of the interactions between participation status and intensity are negative for GVC, OnlyX, and OnlyM firms, confirming the negative association between trade intensity and markups. The joint significance tests confirm that the trade participation and interaction terms are jointly significant for GVC firms and OnlyM firms at the five percent and one percent levels, respectively. The coefficients of OnlyX and OnlyX*Trade intensity are not jointly significant. As in the pooled OLS model, regression (4) includes only the trade intensity variable rather than both the trade participation and intensity variables. The coefficient of the trade intensity variable is significantly negative at the one percent level, confirming that an increase in trade intensity is associated with a reduction in firms' markups. The coefficient of state ownership is insignificant in all of the specifications, most likely because firm ownership type does not frequently change.

\section{B. Does the presence of GVC firms at the industry level influence firms' markups through horizontal, backward, and forward linkages?}

The presence of GVC firms within a domestic value chain may influence competition both within and across industries. GVC firms may increase competition within an industry (horizontal competition), potentially reducing all firms' markups. They may also influence competition vertically. Similar to arguments about spillovers from foreign direct investment (FDI) firms (Javorcik, 2004) ${ }^{16)}$, GVC firms in downstream industries (i.e., potential buyers) may influence competition among upstream suppliers through backward linkages, and their presence in upstream industries (i.e., potential suppliers of intermediate inputs) may affect the performance of and competition experienced by downstream firms through forward linkages. GVC firms can affect competition at different stages of production in many ways; for instance, an emerging cartel may increase downstream or upstream prices, a horizontal or vertical merger may create market power, and a dominant firm within a GVC may abuse its market position to extend its dominance upstream or downstream (World Economic Forum, 2018).

This sub-section explores the influence of the presence of GVC firms, proxied by the share of sales generated by such firms relative to total sales by industry and year, on firms' markups through horizontal, backward, and forward channels. Combining the Ethiopian Manufacturing Census Data for 2000 to 2014 with an input-output table for 2011 taken from the GTAP database, 17) we compute horizontal, backward, and forward variables using a similar methodology to that

16) Javorcik (2004) investigates productivity spillovers from FDI firms to domestic firms through horizontal, backward, and forward linkages. Borrowing her methodology, we investigate whether the presence of a GVC firm at the industry level influences firm-level competition through horizontal, backward, and forward linkages.

17) We map ISIC codes at the four-digit level, which are available for each firm, to 19 GTAP categories using the concordance developed by Francois et al. (2014). 
developed by Javorcik (2004). Because the data rely on the manufacturing census, the backward and forward linkages measured in this section reflect only linkages within manufacturing.

The Horizontal variable is used to proxy for the extent of the presence of GVC firms in industry $j$ at time $t$ and is defined as

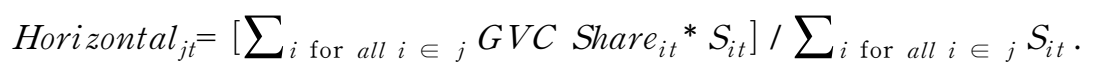

Here, GVC Share $i t$ is the share of sales generated by GVC firm $i$ at time $t$, and $S_{i t}$ is firm $i$ 's total sales at time $t$.

The Backward variable is designed to capture the presence of GVC firms in the industries that are supplied by industry $j$ at time $t$ and is defined as

$$
\operatorname{Backward}_{j t}=\Sigma_{k \text { if } k \neq j} \alpha_{j k} * \text { Horizontal }_{k t}
$$

where $\alpha_{j k}$ is the share of industry $j$ 's output supplied to sector $k$ according to the 2011 inputoutput table from the GTAP database. Intra-industry inputs are not included, as horizontal effects are already captured by the Horizontal variable.

The Forward variable is defined as the weighted share of output in upstream (or supplying) sectors produced by GVC firms.

$$
\text { Forward } \left._{j t}=\Sigma_{m} \text { if } m \neq j \alpha_{j m} \llbracket \Sigma_{i \text { for all } i \in m} G V C \text { Share }_{i t} * S_{i t}\right] /\left[\Sigma_{i \text { for all } i \in m} S_{i t} \rrbracket\right. \text {, }
$$

where $\alpha_{j m}$ is the proportion of total inputs purchased by industry $j$ that are sourced from industry $m$. Appendix Table 2 shows summary statistics for the horizontal, backward, and forward variables by GTAP category.

Regression (1) in Table 6 estimates the relationship between the logarithm of firm markups and our measures of horizontal, backward, and forward linkages with GVC firms. Because our linkage variables are industry-specific, whereas the other variables are based on firm-level data, not adjusting the standard errors is likely to result in a spurious finding of statistical significance for the linkage variables, which are aggregated at the industry level (Javorcik, 2004; Moulton, 1990). Thus, following Javorcik (2004), we correct the standard errors by clustering them for each industry in each year.

The coefficient of the horizontal variable is significantly negative at the one percent level, implying that firms operating in industries with more GVC firms have lower markups relative to firms operating in industries with fewer GVC firms, perhaps because GVC firms bring competition to the sectors in which they operate. Not only do GVC firms have lower markups 
but other firms in the same sector may also need to reduce their markups to compete with the GVC firms that have lower markups.

The coefficient of the backward linkage variable is significantly negative at the one percent level, implying that firms whose industries supply industries with a stronger presence of GVC firms also have lower markups. A potential explanation is that GVC firms are larger and therefore have greater bargaining power vis-a-vis suppliers relative to non-GVC firms (Lianos \& Lombardi, 2016;

Table 6. Exploring the Relationship between Markups and Horizontal, Backward and Forward Linkages

\begin{tabular}{|c|c|c|}
\hline & (1) & (2) \\
\hline \multicolumn{3}{|l|}{ Participation dummies ${ }^{\mathrm{a}}$ : } \\
\hline \multirow[t]{2}{*}{ OnlyX } & -0.065 & -0.028 \\
\hline & $(0.053)$ & $(0.052)$ \\
\hline \multirow[t]{2}{*}{ OnlyM } & $-0.079 * * *$ & $-0.055^{* *}$ \\
\hline & $(0.027)$ & $(0.024)$ \\
\hline \multirow[t]{2}{*}{ GVC } & $-0.117 * *$ & $-0.099 * *$ \\
\hline & $(0.049)$ & $(0.046)$ \\
\hline \multirow[t]{2}{*}{ Horizontal (GVC firms) } & $-0.002 * * *$ & $-0.002 * * *$ \\
\hline & $(0.001)$ & $(0.001)$ \\
\hline \multirow[t]{2}{*}{ Backward (GVC firms) } & $-0.021 * * *$ & $-0.023 * * *$ \\
\hline & $(0.006)$ & $(0.007)$ \\
\hline \multirow[t]{2}{*}{ Forward (GVC firms) } & 0.016 & 0.037 \\
\hline & $(0.058)$ & $(0.056)$ \\
\hline \multirow[t]{2}{*}{ Horizontal (State-owned firms) } & & $0.005^{* * *}$ \\
\hline & & $(0.001)$ \\
\hline \multirow[t]{2}{*}{ Backward (State-owned firms) } & & 0.000 \\
\hline & & $(0.011)$ \\
\hline \multirow[t]{2}{*}{ Forward (State-owned firms) } & & -0.005 \\
\hline & & $(0.012)$ \\
\hline \multirow[t]{2}{*}{ Ownership ( $=1$ if state, $=0$ private $)$} & $0.118^{* * *}$ & $0.088 * * *$ \\
\hline & $(0.020)$ & $(0.019)$ \\
\hline \multirow[t]{2}{*}{ Firm size (log of labor) } & $0.047 * * *$ & $0.048 * * *$ \\
\hline & $(0.010)$ & $(0.010)$ \\
\hline \multirow[t]{2}{*}{ Log of capital } & $-0.016 * * *$ & $-0.016 * * *$ \\
\hline & $(0.004)$ & $(0.004)$ \\
\hline \multirow[t]{2}{*}{ Constant } & $0.694 * * *$ & $0.477 * * *$ \\
\hline & $(0.127)$ & $(0.142)$ \\
\hline Number of observations & 10322 & 10322 \\
\hline $\mathrm{R}^{2}$ & 0.080 & 0.111 \\
\hline
\end{tabular}

Notes: The dependent variable is the log of markup, estimated by the ACF method. a Firms that have no trade (NoXM) are omitted as a reference category.

Standard errors in parentheses have been corrected for clustering by industry and by year. *, **, and *** indicate that the coefficients are significant at the 10,5 , and 1 percent level respectively. 
World Economic Forum, 2018). The coefficient of the forward linkage variable is insignificant, meaning that we identify no competition effect stemming from the presence of GVC firms in industries supplying intermediate inputs.

Regression (2) includes horizontal, backward, and forward linkages for state-owned firms ${ }^{18}$ ), as their presence may influence an industry's competitive environment. The coefficient of the horizontal variable is significantly positive at the one percent level, suggesting that firms operating in industries with a greater presence of state-owned firms have larger markups. When we include linkage variables that proxy for the presence of state-owned firms, the coefficients of the GVC linkage variables remain essentially unchanged.

In sum, the regression results at the industry level are consistent with competition effects resulting from the presence of GVC firms within an industry and through backward linkages. The results also show that the coefficient of the GVC dummy remains significantly negative even after controlling for all of the linkage variables, confirming the robustness of the negative relationship between firms' GVC participation and markups.

\section{Conclusion}

Using panel data from the Ethiopian manufacturing census from 2000 to 2014, this study explored whether GVC firms, defined as firms that both export and import inputs, have different markups relative to non-traders (NoXM) and firms that only export (OnlyX) or import inputs (OnlyM). It also investigated whether the depth of participation in trade affects firms' markups by interacting firms' trade participation status and trade intensity. Moreover, this study explored how industry-level competition resulting from the presence of GVC firms may influences markups through horizontal, backward, and forward linkages.

The Ethiopian Manufacturing Census Data reveal that GVC firms are large in terms of both sales and employment, have more capital-intensive production, are more productive based on labor productivity controlling for capital intensity, and pay higher wages than one-way trading or non-trading firms do, controlling for regional, year, and industry fixed effects. The finding that GVC firms perform better than other firms is in line with the large body of previous work showing that exports and access to imported inputs have positive effects on productivity and product quality and that two-way trading firms are more productive on average than firms that only import or export are. However, few studies have investigated the relationship between GVC participation and markups in low-income countries. This study is meant to help fill this gap by focusing on Ethiopia.

18) The presence of state-owned firms is measured by the share of total sales generated by state-owned firms in each industry and year. 
Using a pooled OLS model, we found that in Ethiopia, GVC firms tend to have lower markups relative to non-trading firms and firms that are involved raw material imports only. Similarly, we used fixed effects models to investigate within-firm variation and found that firms tend to experience reductions in their markups relative to non-trading firms and firms that are involved in only imports when they participate in GVCs. Additionally, we found that the more intensely a firm is integrated into a GVC (measured as the share of export value added and imported inputs in total sales), the lower its markup is. Furthermore, we explored competition effects at the industry level and found that firms operating in industries with a greater presence of GVC firms and suppliers selling inputs to such industries tend to have lower markups through horizontal competition and backward linkages, respectively. All of these findings suggest that GVC participation is associated with greater competition in Ethiopia.

Participation in GVCs appears to create both opportunities and challenges for Ethiopia. We suggest that Ethiopian firms seize any windows of opportunity to participate in GVCs, as doing so may allow them to tap into new markets, become more efficient through competition, and benefit from technology transfers and information by exporting and importing. This experience may provide opportunities for firms to move into higher-valued segments of GVCs. However, the intense competition and low markups earned by GVC participants alarmingly imply that any constraint or barrier at the margin may affect these firms' survival. For instance, manufacturing wages appear to have started rising in Ethiopia (Abreha et al., 2019), which may undermine Ethiopia's competitiveness relative to other low-wage countries. Because Ethiopian GVCs are highly concentrated in a few labor-intensive industries, such as apparel, leather, and footwear products, a concern is that without investment in skills and education, Ethiopia may be locked in (World Bank, 2019a) to relatively low value-added and low-skill segments of production. As wages rise, increasing Ethiopia's capabilities (Gereffi, 2011) through investments in human capital and infrastructure while exercising good policies to ensure a conducive investment climate may determine whether Ethiopian firms will be able to both increase their competitiveness and upgrade themselves to higher value segments of GVCs.

\section{Acknowledgements}

We would like to thank Hibret Belete Maemir and the Central Statistical Authority of Ethiopia for the Ethiopian Manufacturing Census Data. We are also grateful to Ana Margarida Fernandes, Aaditya Mattoo, and anonymous referees of this journal for comments and suggestions. We accept full responsibility for any remaining errors. 


\section{References}

Abreha, K. G. (2019). Importing and firm productivity in Ethiopian manufacturing. The World Bank Economic Review, 33(3), 772-792.

Abreha, K., Jones, P., Lartey E., Mengistae, T., \& Zeufack, A. (2019). Manufacturing job growth in Africa: What is driving it and what will sustain it? The cases of Côte d'Ivoire and Ethiopia (Background paper for the World Bank Africa Chief Economist Office). Industrialization for Jobs Report, World Bank, Washington, DC.

Ackerberg, D., Caves, K., \& Frazer, G. (2006). Structural identification of production functions. MPRA Paper No. 38349.

Amiti, M., \& Konings, J. (2007). Trade liberalization, intermediate inputs, and productivity: Evidence from Indonesia. American Economic Review, 97(5), 1611-1638.

Antràs, P., Chor, D., Fally, T., \& Hillberry, R. (2012). Measuring the upstreamness of production and trade flows. American Economic Review, 102(3), 412-416.

Autor, D., Dorn, D., Katz, L. F., Patterson, C., \& Van Reenen, J. (2017). Concentrating on the fall of the labor share. American Economic Review, 107(5), 180-185.

Bas, M., \& Strauss-Kahn, V. (2015). Input-trade liberalization, export prices and quality upgrading. Journal of International Economics, 95(2), 250-262.

Békés, G., Hornok, C., \& Muraközy, B. (2016). Globalization and the markups of European firms (Discussion Paper 2044). Kiel Institute for the World Economy.

Bellone, F., Musso, P., Nesta, L., \& Warzynski, F. (2016). International trade and firm-level markups when location and quality matter. Journal of Economic Geography, 16(1), 67-91.

Bigsten, A., Collier, P., Dercon, S., Fafchamps, M., Gauthier, B., Willem Gunning, J., Oduro, A., Oostendorp, R., Pattillo, C., Söderbom, M., \& Teal, F. (2004). Do African manufacturing firms learn from exporting? Journal of Development Studies, 40(3), 115-141.

Bigsten, A., Gebreeyesus, M., \& Söderbom, M. (2016). Tariffs and firm performance in Ethiopia. The Journal of Development Studies, 52(7), 986-1001.

Brandt, L., Van Biesebroeck, J., Wang, L., \& Zhang, Y. (2017). WTO accession and performance of Chinese manufacturing firms. American Economic Review, 107(9), 2784-2820.

Castellani, D., Serti, F., \& Tomasi, C. (2010). Firms in international trade: Importers' and exporters' heterogeneity in Italian manufacturing industry. World Economy, 33, 424-457.

De Loecker, J., \& Eeckhout J. (2017). The rise of market power and the macroeconomic implications (Working Paper Number 23687). National Bureau of Economic Research, Cambridge, MA.

De Loecker, J., \& Eeckhout, J. (2018). Global market power (Working Paper Number 24768). National Bureau of Economic Research, Cambridge, MA.

De Loecker, J., Goldberg, P. K., Khandelwal, A. K., \& Pavcnik, N. (2016). Prices, markups, and trade reform. Econometrica, 84(2), 445-510.

De Loecker, J., \& Warzynski, F. (2012). Markups and firm-level export status. American Economic Review, 102(6), 2437-2471.

Dewenter, K. L., \& Malatesta, P. H. (2001). State-owned and privately-owned firms: An empirical analysis 
of profitability, leverage, and labor intensity. American Economic Review, 91(1), 320-334.

Diez, M. F. J., Fan, J., Villegas-Sánchez, C. (2019). Global declining competition (Working Paper WP/19/82). International Monetary Fund, Washington, DC.

Fatou, C., \& Choi, J. (2013). Do firms learn by exporting or learn to export: Evidence from Senegalese manufacturers' plants (Working Paper Series 191). African Development Bank, Tunis, Tunisia.

Fernandes, A. M., Freund, C., \& Pierola, M. (2016). Exporter behavior, country size and stage of development: Evidence from the Exporter Dynamics Database. Journal of Development Economics, 119, 121-137.

Francois, J., Manchin, M., \& Tomberger, P. (2014). Explanatory note: Export of value-added database. The export value added database documentation. World Bank, Washington, DC. Retrieved from https://datacatalog.worldbank.org/dataset/export-value-added-database

Freund, C., \& Pierola, M. (2015). Export superstars. Review of Economics and Statistics, 97(5), 1023-1032.

Gereffi, G. (2011). Global value chains and international competition. The Antitrust Bulletin, 56(1), 37-56.

Goldberg, P. K., Khandelwal, A. K., Pavcnik, N., \& Topalova, P. (2009). Trade liberalization and new imported inputs. American Economic Review, 99(2), 494-500.

Gradzewicz, M., \& Mućk, J. (2019). Globalization and the fall of markups. Warszawa, Poland: Narodowy Bank Polski Education \& Publishing Department.

Gullstrand, J., Olofsdotter, K., \& Thede, S. (2014). Markups and export-pricing strategies. Review of World Economics, 150(2), 221-239.

Gupta, N. (2005). Partial privatization and firm performance. The Journal of Finance, 6(2), 987-1015.

Halpern, L., Koren, M., \& Szeidl, A. (2015). Imported inputs and productivity. American Economic Review, 105(12), 3660-3703.

Hornok, C., \& Muraközy, B. (2019). Markups of exporters and importers: Evidence from Hungary. The Scandinavian. Journal of Economics, 121(3), 1303-1333.

Hummels, D., Ishii, J., \& Yi, K. (2001). The nature and growth of vertical specialization in world trade. Journal of International Economics, 54(1), 75-96.

Javorcik, B. (2004). Does foreign direct investment increase the productivity of domestic firms? In search of spillovers through backward linkages. American Economic Review, 94(3), 605-627.

Johnson, R. C., \& Noguera, G. (2012). Accounting for intermediates: Production sharing and trade in value added. Journal of International Economics, 86(2), 224-236.

Jones, P., Mengistae, T., \& Zeufack, A. (2018). Selection, firm turnover, and productivity growth: Do emerging cities speed up the process? (Working Paper No. 8291). World Bank, Washington, DC.

Kato, A. (2014). Does export yield productivity and markup premiums? Evidence from the Japanese manufacturing industry (Discussion Paper Series 14-E-037). Research Institute of Economy, Trade, and Industry.

Kee, H. L., \& Tang, H. (2016). Domestic value added in exports: Theory and firm evidence from China. American Economic Review, 106(6), 1402-1436.

Koopman, R., Wang Z., \& Wei, S. J. (2014). Tracing value-added and double counting in gross exports. American Economic Review, 104(2), 459-494.

Lianos, I., \& Lombardi, C. (2016). Superior bargaining power and the global food value chain: The Wuthering Heights of holistic competition law? (Research Paper Series 1/2016). Centre for Law, 
Economics and Society.

Linden, G., Kenneth, K. L., \& Dedrick, J. (2009). Who captures value in a global innovation network? The case of Apple's iPod. Communications of the ACM, 52(3), 140-144.

Los, B., Timmer, M. P., \& de Varies G. J. (2015). How global are global value chains? A new approach to measure international fragmentation. Journal of Regional Science, 55(1), 66-92.

Megginson, W. L., \& Netter J. M. (2001). From state to market: A survey of empirical studies on privatization. Journal of Economic Literature, 39(2), 321-389.

Melitz, M. J., \& Ottaviano, G. I. (2008). Market size, trade, and productivity. The Review of Economic Studies, 75(1), 295-316.

Mengistae, T., \& Pattillo, C. (2004). Export orientation and productivity in sub-Saharan Africa. IMF Staff Papers, 51(2), 327-353.

Moulton, B. R. (1990). An illustration of a pitfall in estimating the effects of aggregate variables on micro units. The Review of Economics and Statistics, 72(2), 334-338.

Oqubay, A. (2015). Made in Africa: Industrial policy in Ethiopia. New York: Oxford University Press.

Smeets, V., \& Warzynski, F. (2013). Estimating productivity with multi-product firms, pricing heterogeneity and the role of international trade. Journal of International Economics, 90(2), 237-244.

Taglioni, D., \& Winkler, D. (2016). Making global value chains work for development. Washington, DC: World Bank.

Timmer, M. (Ed.) (2012). The World Input-Output Database (WIOD): Contents, sources and methods. WIOD Working Paper 10.

Timmer, M. P., Miroudot, S., \& de Vries, G. J. (2019). Functional specialization in trade. Journal of Economic Geography, 19(1), 1-30.

Topalova, P., \& Khandelwal, A. (2011). Trade liberalization and firm productivity: The case of India. Review of Economics and Statistics, 93(3), 995-1009.

Van Biesebroeck, J. (2005). Exporting raises productivity in sub-Saharan African manufacturing firms. Journal of International Economics, 67(2), 373-391.

Vogel, A., \& Wagner., J. (2010). Higher productivity in importing German manufacturing firms: Self-selection, learning from importing, or both? Review of World Economics, 145(4), 641-665.

Wang, Z., Wei, S. J., \& Zhu, K. (2013). Quantifying international production sharing at the bilateral and sector levels (Working Paper Number w19677). Cambridge, MA: National Bureau of Economic Research.

World Bank. (2019a). World development report 2020: Trading for development in the age of global value chains. Washington, DC: World Bank.

World Bank. (2019b). World development indicators. Retrieved from https://databank.worldbank.org/report s.aspx?source=world-development-indicators\#

World Economic Forum. (2018). Global value chain policy series: Competition. Retrieved from https://ww w.weforum.org/whitepapers/global-value-chain-policy-series-competition-ad360d8f-fcf6-4d91-89fe-27 453427bb14 


\section{Appendix}

Table A1. Summary Statistics

\begin{tabular}{lccccc}
\hline Variable & No. of obs. & Mean & SD & Min & Max \\
\hline Log of markup & 10324 & 0.51 & 0.42 & -0.69 & 2.46 \\
$\begin{array}{l}\text { Participation dummies } \\
\text { GVC }\end{array}$ & 10324 & 0.05 & 0.22 & 0.00 & 1.00 \\
$\quad$ OnlyX & 10324 & 0.01 & 0.10 & 0.00 & 1.00 \\
OnlyM & 10324 & 0.62 & 0.49 & 0.00 & 1.00 \\
$\quad$ NoXM & 10324 & 0.32 & 0.47 & 0.00 & 1.00 \\
State ownership & 10324 & 0.10 & 0.30 & 0.00 & 1.00 \\
Firm size (log of labor) & 10324 & 3.56 & 1.37 & 0.00 & 8.98 \\
Log of capital & 10324 & 13.63 & 2.78 & -0.38 & 21.54 \\
Upstream Index & 10324 & 1.54 & 0.51 & 1.00 & 2.60 \\
Trade intensity & 10226 & 0.20 & 0.25 & 0.00 & 1.00 \\
\hline
\end{tabular}

Notes: The figures reflect only the observations included in the regressions. The observations without two consecutive years are dropped since the ACF method requires them.

(Source) Ethiopian Manufacturing Census Data 2000-2014.

Table A2. Presence of GVC and State-owned Firms in Horizontal, Backward and forward Linkages, by Industry

\begin{tabular}{|c|c|c|c|c|c|c|c|}
\hline \multirow[b]{2}{*}{ GTAP } & \multirow[b]{2}{*}{ Description } & \multicolumn{3}{|c|}{ Presence of GVC firms (\%) } & \multicolumn{3}{|c|}{ Presence of Stat-owned Firms (\%) } \\
\hline & & $\begin{array}{l}\text { Horizontal } \\
\text { (GVC) }\end{array}$ & $\begin{array}{c}\text { Backward } \\
\text { (GVC) }\end{array}$ & $\begin{array}{c}\text { Forward } \\
(\mathrm{GVC})\end{array}$ & $\begin{array}{c}\text { Horizontal } \\
\text { (State) }\end{array}$ & $\begin{array}{c}\text { Backward } \\
\text { (State) }\end{array}$ & $\begin{array}{c}\text { Forward } \\
\text { (State) }\end{array}$ \\
\hline b_t & Beverages \& tobacco & 36.510 & 0.000 & 0.060 & 33.600 & 0.000 & 0.835 \\
\hline Crp & Chemical rubber products & 3.023 & 6.836 & 0.177 & 23.796 & 3.963 & 0.564 \\
\hline Ele & Electronic equipment & 0.429 & 0.046 & 0.477 & 0.000 & 0.671 & 1.140 \\
\hline Fmp & Fabricated metal & 1.320 & 0.280 & 0.034 & 22.184 & 1.904 & 1.212 \\
\hline i_s & Iron \& steel & 2.220 & 0.022 & 0.099 & 26.061 & 0.397 & 0.491 \\
\hline Lea & Leather & 73.323 & 0.175 & 0.249 & 21.303 & 0.100 & 0.959 \\
\hline Lum & Lumber & 0.800 & 0.072 & 0.263 & 20.041 & 0.298 & 0.933 \\
\hline Mil & Dairy products & 3.039 & 0.029 & 0.042 & 24.046 & 0.123 & 0.748 \\
\hline Mvh & Motor vehicles and parts & 0.000 & 0.000 & 0.090 & 12.071 & 0.001 & 0.960 \\
\hline $\mathrm{Nfm}$ & Non-ferrous metals & 0.000 & 0.488 & 0.134 & 2.222 & 5.783 & 0.887 \\
\hline $\mathrm{Nmm}$ & Non-metallic minerals & 1.258 & 0.209 & 0.045 & 52.259 & 0.294 & 0.317 \\
\hline Ofd & Other food & 6.359 & 0.008 & 0.144 & 27.501 & 0.008 & 0.754 \\
\hline Ome & Other machinery & 0.203 & 0.002 & 0.047 & 0.230 & 0.006 & 0.567 \\
\hline $\mathrm{Omf}$ & Other manufacturing & 0.000 & 0.005 & 0.297 & 0.000 & 0.015 & 1.220 \\
\hline Omt & Other meat (pig meat \& offal) & 9.080 & 5.099 & 0.084 & 32.689 & 4.828 & 0.347 \\
\hline Ppp & Paper \& paper products & 0.290 & 1.972 & 0.164 & 44.927 & 2.773 & 1.321 \\
\hline Sgr & Sugar & 55.560 & 2.108 & 0.116 & 97.973 & 2.312 & 1.155 \\
\hline Tex & Textiles & 41.877 & 0.505 & 0.289 & 37.168 & 0.303 & 1.273 \\
\hline Wap & Wearing apparel & 31.557 & 0.001 & 0.226 & 17.777 & 0.000 & 0.952 \\
\hline & Total & 14.045 & 0.940 & 0.160 & 26.097 & 1.251 & 0.875 \\
\hline
\end{tabular}

(Source) Ethiopian Manufacturing Census Data 2000-2014; Global Trade Analysis project (GTAP) database (Version 9). 